\title{
Compensating Wage Differentials for Schooling Risk in Denmark*
}

\author{
Luis Diaz-Serrano* \\ National University of Ireland, Maynooth \\ CREB, Barcelona \\ Joop Hartog \\ SCHOLAR, University of Amsterdam \\ Helena Skyt Nielsen ^ \\ University of Aarhus
}

\begin{abstract}
In this paper we test for risk compensation in wages using Danish panel data. With the conviction that the type of education is as important as the education length, we use a very detailed description of the type of education reached by the Danish population to calculate different measures of risk. Our long panel data set also allows us to decompose shocks in earnings in a permanent and a transitory component. We test the role of the risks associated to both components in wage compensation. We also experiment with new measures of risk based on intertemporal fluctuations on transitory shocks in earnings. Thus, we get closer to risk measures catching the intrinsic long-run feature of schooling-risks and the required compensation. In concordance to what theory predicts, we find that the labor market compensates for such foreseeable risks. Hence, we state a return-risk trade-off for the human capital investments in Denmark.
\end{abstract}

Keywords: Risk-premium, skewness affection, Schooling risk, earnings shocks.

JEL classification: D8, J3

Preliminary version, please do not quote.

This version: $23 / 9 / 2003$

File: SchoolriskDK.doc

\footnotetext{
${ }^{*}$ We appreciate financial support from the Danish Research Agency. This paper has been written while Luis Diaz-Serrano visited the Aarhus School of Business.

* Department of Economics, National University of Ireland Maynooth, Co. Kildare, Ireland. E-mail: Luis.Diaz@may.ie.

- Department of Economics. Universiteit van Amsterdam. Roetersstraat, 11. 1018WB Amsterdam. (The Netherlands). E-mail: J.Hartog@uva.nl; Hartog is a Fellow of Tinbergen Institute, IZA and CESifo

• Department of Economics, University of Aarhus, Ndr. Ringgade 1, DK-8000 Aarhus C (Denmark). Email: hnielsen@econ.au.dk
} 


\section{Introduction and motivation}

After many decades of empirical research, there is no doubt that education is, on average, a profitable investment. A general agreement exists that besides being profitable, education is also a risky investment. At least two possible sources of risk can be found. First, a priori individuals may not be able to evaluate if their abilities will suffice to successfully complete the chosen level of education. And second, even if the educational process is completed successfully, they do not know where in the earnings distribution they will end up. In this paper we study the effect that this second source of risk (earnings uncertainty) exerts on wages. To the extent that the individual cannot ensure his/her returns to schooling and the variance of earnings is not constant across education, the risk premium in wages becomes as important as the average returns. While the latter has been widely studied, the risk premium has received little attention. Even though risk has been accounted for in several theoretical models, it has rarely been tested in an empirical context. Theory suggests that if risks are foreseeable they should be compensated for. The small empirical evidence on this subject confirms this theory ${ }^{1}$. Moreover, Hartog and Vijverberg (2002) claim that individuals display preference for a skewed earnings distribution, since they appreciate the low probabilities to obtain substantial incomes. Thus, in addition to testing the existence of risk compensation in wages, we also try to find evidence for what they call skewness “affection”.

Previous works dealing with risk compensation in wages have estimated risk as the variance in earnings by occupation cells. Skewness is measured in a similar way. In an attempt to assess risk compensation in wages more accurately, Hartog and Vijverberg (2002) used occupation-education level cells. In this paper we are able to measure the risk and skewness of the earnings associated with the type of education only. We use a variable containing a detailed description on the highest educational level reached by Danes. We consider that a risk measure based only on education cells is closer to the true risk associated with the schooling investment. When the investment decision is made, individuals do not know their future occupation only their education. With observations by schooling type, there is no problem of selective mobility that beset observations by occupation as used by Hartog and Vijverberg (2002) to generate sufficient observations on risk. Thus, our data base

\footnotetext{
${ }^{1}$ King (1974), Feinberg (1981), McGoldrick (1995), and Hartog, Plug, Diaz-Serrano and Vieira (2003).
} 
constitutes by itself a substantial improvement over previous empirical literature. We allow for the fact that within a given schooling level, both returns and risk may vary across educational types. For example, it is plausible that earnings distributions within the fields of Economics and Law, which attract more students, differ from those in for instance Engineering.

Taking as baseline the work in Hartog and Vijberberg (2002), in this paper we attempt to provide new empirical evidence on risk compensation in wages using Danish data. In contrast to previous literature dealing with this subject that reports evidence mainly based on cross-section data, we use a panel consisting of a 10 percent sample of the whole Danish population aged 16 and above observed during 17 years (about 500,000 observations per year). Using such a big panel allows us to separate permanent from transitory shocks in earnings, and to test if risks arising from both types of shocks are compensated for and in what manner. At the same time, our dataset also allows to experiment with new measures of risk based on earnings mobility. Thus, our contribution is not only based on the use of a wide range of educational types in measuring risk, but also on introducing a new dynamic dimension in the estimation of risk compensating differentials. Our results confirm the existence of such compensation in wages. With the aims described above, the remainder of the paper is structured as follows. In section 2 we review the existing literature dealing with risk, education and wages. In section 3 we develop a simple model on risk compensating differentials. Section 4 provides a detailed description of the data used throughout this paper. Section 5 describes the risk measures used and reports the empirical results. Finally, section 6 presents a discussion on the main implications of our empirical results and concludes.

\section{Previous literature}

In the economic literature, earnings uncertainty (hereafter risk) has received considerable attention. Three different approaches have been proposed. The first and most widely used approach focuses on the effect of risk on human capital investment decisions. In their seminal work Levhari and Weiss (1974) use a two-period model of educational choice and find that earnings risk acts as a disincentive on the investment in human capital. Applying also a two-period model, Eaton and Rosen (1980) analytically confirm the results by 
Levhari and Weiss, while Kodde (1986) rejects them empirically by observing the contrary effect. Using a the dynamic programming framework, Williams (1979) obtains that higher risk reduces the investment in human capital. Just the opposite conclusion is found by Hogan and Walker (2001) and Belzil and Hansen (2002). Hartog and Diaz-Serrano (2002) also analyse the effect of the stochastic post-school earnings on the optimal educational length. Their theoretical model predicts that increasing risk in future income should exert a negative effect on the individual's educational length for risk-averse individuals and positive for "risk-lovers". These forecasts are validated by empirical findings using Spanish data.

The second approach establishes a link between the returns to schooling, as commonly defined in the Mincerian earnings equations, and risk. Low and Ormiston (1991) considered the firsts two moments (mean and variance) of the earnings distribution in the individual's utility function, hence they allow the returns to education to vary with the individuals' degree of risk aversion. They find that education has a positive impact on the variance of earnings, and the returns to education tend to decrease as the individual's level of risk aversion increases. Their findings come close to the theory we maintain that individuals facing more risk in future incomes have greater expectations for higher earnings. Harmon, Hogan and Walker (2003) specify a Mincerian earnings equation and include a variation in the parameter associated to years of schooling. They consider returns to schooling as a random coefficient. Both works represent one step further in the estimation of the returns to schooling in a risky world, where individuals differ in their level of risk aversion. Neither Hogan et al nor Ormiston and Low attempt to measure risk compensation in wages, as we do here; moreover, Ormiston and Low use a very unattractive utility function, with the reservation premium for risk increasing in income and decreasing in risk.

The third approach, in which the present work can be inserted, deals with risk compensation in wages. Although the literature on this subject is scarce and mainly focused on the US labour market, the empirical results are very consistent. Weiss (1972) was the first to consider the variance of earnings by educational levels and to correct the estimated rates of returns to schooling for different degrees of risk aversion. In a paper by King (1974) the standard deviation and skewness of earnings, computed by occupations, are regressed on the average earnings. The author finds that riskier occupations (higher variance in earnings) are associated with higher mean incomes. Using a six- year panel on hourly wages, 
Feinberg (1981) accounts for the existence of compensating differentials for increased earnings-risk, measured as the individual's intertemporal variations in earnings. He calculates the intertemporal coefficient of variation of individual earnings, and includes it as a covariate in a cross-sectional regression (last year of the panel).

McGoldrick (1995) and McGoldrick and Robst (1996) also report significant compensating differentials for earnings uncertainty and penalty for skewness affection for men and women. McGoldrick's (1995) work introduces an important novelty by distinguishing between systematic and unsystematic earnings. She estimates a two-step model. First, unsystematic earnings are estimated as the residuals of a standard Mincerian earnings equation that uses as regressors those variables that tend to create systematic variations in earnings (years of schooling, age or geographical location). Second, once systematic variations (variations not associated with earnings risk) are removed from earnings, the variance and skewness of the first-step residuals are included as regressors in a Mincer equation. Applying this technique to Spanish data, Diaz-Serrano $(2001)^{2}$ finds significant risk compensation and skewness penalty. Hartog, Plug, Diaz-Serrano and Vieira (2003) obtain the same result for The Netherlands, Germany, Spain and Portugal.

Our point of departure is the research on risk compensating differentials developed by Hartog and Vijverberg (2002), who support the empirical findings with a formal theoretical model. They test risk compensation and skewness affection in wages for the US labour market using a wide variety of measures derived from their theoretical model ${ }^{3}$ by using both reduced form and structural earnings equations. Christiansen and Nielsen (2002) analyse the risk-premium in wages using a Mean-Variance type of model, and thus establish a link between human capital and finance literature. They employ very detailed data on education (the same used here), which allows them to base the risk measure only on educational levels (110 cells). Using 11 years of Danish panel data, the authors find a positive and significant effect of risk on wages. However, they do not account for skewness affection, which is crucial in assessing the magnitude and the sign of the risk-premium. Using cross-country data, Pereira and Martins (2002) establish a positive link between risk as measured from quantile regressions and returns to education.

\footnotetext{
${ }^{2}$ Similar to King (1974), this author also concludes that individuals coming from wealthier families tend to choose riskier occupations (decreasing risk-aversion).

${ }^{3}$ All previous studies estimate risk using the standard formula of the variance in earnings or their estimated residuals from a Mincer equation.
} 


\section{Conceptual framework}

Our framework is similar to that presented in Hartog and Vijverberg (2002). Individuals face several schooling options and will only undertake them if they are sufficiently compensated. The basic Mincer earnings function allows for compensation for earnings postponement, under strict assumptions implying a constant mark-up for every additional year of schooling. In our approach we allow for the fact that individuals considering an education generally do not face some fixed income after completing a certain education. Instead they face an entire income distribution depending on the exact education which has been chosen. Thus, investing in schooling is a risky venture as an individual simply does not know where in this distribution she will end up. Risk averse individuals will want compensation for this risk. This risk premium will emanate from market supply reactions to the wage differential for options differing in earnings risk. Insufficient risk compensation will reduce supply of labour with that education and push up the wage, until equilibrium is established.

To be more specific, assume individuals can choose between educations, equal in length, intrinsic attractivity, etc. During an education individuals accumulate human capital, but upon entering the education they do not know how much, as they do not know their aptitude for this education. The accumulation of human capital differs between individuals. Individuals know the parameters of the probability distribution for the amount of human capital at the end of the schooling period. After leaving school, their amount of human capital is public knowledge.

There is a market for human capital that determines a market clearing price per efficiency unit of human capital for every education (human capital is heterogeneous across educations, homogeneous within educations). The supply of new human capital equals the probability distribution of human capital upon graduation, multiplied by the number of graduates. Total supply equals the supply of new human capital (new graduates) plus the predetermined stock of existing human capital. Demand, in units of human capital, is a declining function of the unit price. Equality of supply and demand of human capital determines the equilibrium unit price. The expected earnings in an education, at the moment of deciding on entering this education, are equal to expected level of human capital upon graduation multiplied by the unit price of human capital (actual earnings when graduating 
are equal to realised level of human capital multiplied by the unit price). We can only have long run equilibrium if the difference in expected earnings in two educations matches the required compensation for differences in risk. This requires a particular supply of new entrants to an education.

To simplify the exposition, suppose there are two options open to a potential student. The two educations are identical in all relevant aspects except for the distribution of human capital at the end of the education. Say education 2 has a greater variance of human capital upon graduation. With market clearing through equilibrium unit price operating for both educations, this translates into different variances of earnings for individuals contemplating the direction of their education. Assume all individuals are equally risk averse, implying some desired risk premium in the expected wage for education 2 relative to education 1. The realised wage differential between the two educations is determined by relative supplies of workers with the two educations. A shift from education 2 to education 1 will increase the unit price (wage) in education 2 and reduce the unit price in education 1 (because both educations have declining demand curves for human capital), thus increasing the wage gap. A long-run equilibrium exists if supply is distributed over both educations in such a way that the bid prices from the demand curves generate a wage differential that individuals find exactly compensating for the difference in risk.

So far, we only consider risk due to uncertainty about the output of the schooling process. In terms of earnings distribution this is an individual fixed effect or permanent risk: human capital produced in school is given for the rest of working life. Now, let's add intertemporal risk. Suppose, for individuals with a given education there is some process of accumulating human capital during working life. Again, within an educational category, human capital is homogeneous. So, the market clearing unit price is determined at the intersection of the total demand curve for human capital of a given type and total supply: number of new graduates multiplied by mean level of human capital produced in school plus number of workers of each experience class multiplied by their level of human capital. Suppose the demand curve is shocked every year: the equilibrium value of a unit of human capital fluctuates randomly over time. Assume the parameters of this process are public knowledge. Then individuals embarking on an education know how much intertemporal variation in earnings they must anticipate. As before, they will take that into account when choosing their education, and only enter when the compensation for risk is sufficient. With 
a given stock of experienced workers, long-run equilibrium again obtains if the number of entrants leads to supplies that precisely uphold the wage gap requested as risk compensation. ${ }^{4}$

We can derive the required compensation for risk from imposing equal expected lifetime utility for all educations. For the sake of exposition, we assume that there is one option that has fixed earnings in every year that an individual works. We ignore experience effects for individuals in all options. We will also ignore compensation for postponing earnings when going to school, as this is taken care of in the usual Mincer mark-up.

Consider first the permanent effect from risky human capital production. In the riskless alternative, annual earnings are given as $Y_{f}$, generating utility $U\left(Y_{f}\right)$, where $U($ ) is a concave utility function with $U^{\prime}>0, U^{\prime}<0$ and $U^{\prime \prime},>0$ (the latter condition is necessary for declining absolute risk aversion, see Tsiang, 1974 or Hartog and Vijverberg, 2002). In the risky option, income is a single draw for the rest of working life, written as $Y_{r}+\varepsilon$ equal expected lifetime utility requires

$$
\int_{0}^{T} U\left(Y_{f}\right) e^{-\rho t} d t=E \int_{0}^{T} U\left(Y_{r}+\varepsilon\right) e^{-\rho t} d t
$$

where $\mathrm{T}$ is the length of working life and $\rho$ the time discount rate. We can write the lefthand side as

$$
\int_{0}^{T} U\left(Y_{f}\right) e^{-\rho t} d t=\frac{1}{\rho}\left(1-e^{-\rho T}\right) U\left(Y_{f}\right)
$$

For the stochastic term on the right-hand side we apply a third-order Taylor expansion around the expected value $Y_{f}$, one order up from Pratt's original contribution (Pratt, 1964),

to

$$
\int_{0}^{T} U\left(Y_{r}+\varepsilon\right) e^{-\rho t} d t=\frac{1}{\rho}\left(1-e^{-\rho T}\right)\left[U^{\prime}\left(Y_{r}\right)+\frac{1}{2} U^{\prime \prime}\left(Y_{r}\right) \sigma_{a}^{2}+\frac{1}{6} U^{\prime \prime \prime}\left(Y_{r}\right) \kappa_{a}^{3}\right]
$$

\footnotetext{
${ }^{4}$ Random fluctuation of the demand for human capital is only one way of generating intertemporal earnings risk. Stochastic production of human capital in on-the-job training and job search processes are alternatives. The precise underpinning of intertemporal risk is immaterial for our purpose, all we need is a foreseeable intertemporal earnings risk in an individual's working life.
} 
where $\sigma_{\mathrm{a}}^{2}$ is the second moment (risk) and $\kappa_{\mathrm{a}}^{2}$ is the third moment (skewness) of $\varepsilon$ around the expected value zero. Equating (2) and (3) and rewriting a little, after applying a firstorder Taylor expansion around $Y_{r}$ for (2), we get

$$
\frac{Y_{r}-Y_{f}}{Y_{r}}=-\frac{1}{2} \frac{\sigma_{a}^{2}}{Y_{r}^{2}} \frac{U^{\prime \prime}}{U^{\prime}} Y_{r}-\frac{1}{6} \frac{\kappa_{a}^{3}}{Y_{r}^{3}} \frac{U^{\prime \prime}}{U^{\prime \prime}} Y_{r} \frac{U^{\prime \prime}}{U^{\prime}} Y_{r}=\frac{1}{2} \frac{\sigma_{a}^{2}}{Y_{r}^{2}} V_{r}-\frac{1}{6} \frac{\kappa_{a}^{3}}{Y_{r}^{3}} V_{s} V_{r}
$$

where $V_{r}$ is Arrow-Pratt's relative risk aversion and $V_{s}$ is the similar definition for relative skewness affection (we call it affection, because individuals like skewness; see Hartog and Vijverberg, 2002). With $V_{r}$ and $V_{s}$ positive by definition, we note from (4) that individuals will only enter an education if the permanent effect from unknown human capital production is matched by a positive premium for the risk (variance), while they allow an earnings drop for skewness.

Let's now consider the transitory component of risk. Again, let there be a riskless option, with earnings fixed at $Y_{f}$ for the rest of working life, and a stochastic option given by

$$
\begin{gathered}
Y_{r t}=Y_{r}+\varepsilon_{t} \\
E\left(\varepsilon_{t}\right)=0, \quad E\left(\varepsilon_{t}^{2}\right)=\sigma_{a}^{2}, \quad E\left(\varepsilon_{t}^{3}\right)=\kappa_{a}^{3}, \quad E\left(\varepsilon_{t} \varepsilon_{s}\right)=0, \quad t \neq s
\end{gathered}
$$

We now take $Y_{r}$ as fixed: it's the initial draw from the earnings distribution that contains the permanent effect discussed above ${ }^{5}$. Applying the same rules as above, we derive

$$
\frac{Y_{r}-Y_{f}}{Y_{r}}=\frac{1}{2} \frac{\sigma_{a}^{2}}{Y_{r}^{2}} V_{r}-\frac{1}{6} \frac{\kappa_{a}^{3}}{Y_{r}^{3}} V_{s} V_{r}
$$

Just as for permanent shocks, individuals want compensation for the risk involved in the annual shocks $\sigma_{\mathrm{a}}^{2}$ and are willing to pay for the skewness in the annual shocks $\kappa_{\mathrm{a}}^{3}$. So far, we have assumed that individuals only know the parameters of the distributions of human capital production in school and shifts in demand (equilibrium unit prices) over time. It is this risk they need to be compensated for. But suppose they would have full information over their individual fixed effect: individuals can perfectly predict how much human capital

\footnotetext{
${ }^{5}$ Instead of annual shocks coming from the same distribution every year, we might make the distribution conditional on time or experience. We have decided to leave such complications for later work.
} 
they will get out of the education, or, less demanding, they perfectly predict their ranking in the human capital distribution. In that case, the individual fixed effect entails no risk as individuals themselves simply know the realized value and not only the distribution they draw from. Hence they would require no compensation. Thus, including the fixed effect in an empirical analysis is a test on information: if individuals are sure of their position in the distribution upon graduation, they will not be compensated for the dispersion in that distribution, if they don't know it, it will be a risk for them and they need such compensation. More generally we can say that the extent of compensation for permanent variability relative to transitory variability will reflect the relative degree of information that individuals have on their prospects, i.e a relative measure of risk versus individual heterogeneity ${ }^{6}$. Similarly, the correlation between the transitory and permanent variability would suggest whether the permanent variability might reflect foreseeable earnings risk. If the correlation is high, it is unlikely that the permanent variability just reflects individual heterogeneity.

\section{The data}

We use data collected by Denmark Statistics, which represents a 10 percent random sample of the Danish population aged between 16 and 75 over the period 1984-2000 (about 500,000 individuals per year). The data contains detailed information on the individuals' labour situation, occupation, education, social and family status. The variables we use in this study are real gross yearly earnings, age, occupation, industry, and the highest level of education attained. The education variable contains 1,750 different categories. Nevertheless, in order to have a representative number of individuals in each education cell, we group this variable in a new one with 75 categories. In order to avoid selectivity problems on female labour force participation we restrict our sample to male wage earners. We start by selecting those cohorts of working men who were aged between 30 and 40 in 1984. There are three reasons for imposing this age restriction. First, we avoid selectivity problems due to early retirement decisions. Second, we ensure that the selected individuals have already completed their educational process. And third, by excluding young workers entering the

\footnotetext{
${ }^{6}$ We owe this interpretation to Wim Vijverberg
} 
labour market and individuals close to retirement we make sure that our measure of dispersion is more indicative of true structural dispersion for that education.

We select only full-time workers (more than 30 hours per week) that have worked during the whole year. Unemployed and individuals out of the labor force are dropped from the sample for that year in order to focus on earnings risk rather than unemployment risk or labour market participation. Gross yearly earnings are the real annual individual labor earnings measured in DKK. We use the 2000 consumer price index to calculate individual real earnings. Table 1 describes the educational groups and provides some summary statistics.

Insert table 1

The panel data commonly used in the earnings literature are mainly based on social security or tax records. The most important advantage of these panels is the large sample size, and the basic limitation is the scarcity of demographic information. Our panel not only has the advantage of containing a large sample size, but also provides detailed demographic information. After applying the above mentioned filters we are left with a representative sample of about 30,000 individuals per year, of whom about 18,000 individuals are observed continuously every year between 1984 and 2000. Throughout this study we will use an unbalanced panel. Summary statistics of the different panel samples are presented in tables 2, 3 and 4 . In table 2 we describe the entire sample. Table 3 provides detailed information about sample sizes by cohorts and the number of years that each cohort is observed. In table 4 we present statistics on the first three moments of the log-earnings distribution for each year in the panel.

Insert table 2

Insert table 3

Insert table 4

\section{Estimation and results}

In this section we propose and estimate different measures of risk (hereafter $R$ ) and skewness (hereafter $K$ ). To test the existence of risk compensating differentials and 
skewness affection we use reduced form wage equations; we include these measures of $R$ and $K$ as regressors in a Mincer earnings equation ${ }^{7}$. Our estimation strategy divides this section in three parts. First, we estimate $R$ and $K$ and test compensation by using singleyears cross-sections. In this part, we take the 17 years panel of our data set as 17 different cross-sections. Second, we use our panel data to compute longitudinal measures of $R$ and $K$ and test the effect of both in the last year panel wages (2000). And third, also within the panel data context, we estimate $R$ using different measures of earnings mobility and test compensation proceeding as in the second part. Throughout this section, we compute $R$ and $K$ using the wide range of types of education provided by our data set, aggregated into 75 groups that allow us to get a representative sample in each education cell.

\subsection{Cross-section estimation}

In this part we estimate the different measures of $\mathrm{R}$ and $\mathrm{K}$ using the same data set containing the individual's wages used to compute the Mincer earnings equations. Thus, as it is done in McGoldrick (1995), Hartog and Vijverberg (2002), and Hartog, Plug, DiazSerrano and Vieira (2003) we proceed to calculate R and K by a quite straightforward twostep procedure. We first estimate for each year separately the following cross-section logearnings equation

$$
\ln Y_{i j}=X_{i} \beta+\sum_{j} \alpha_{j} d_{j}+\varepsilon_{i j}
$$

where the subscripts $i$ and $j$ denote individuals and the education cell where the individual belongs to respectively. $Y$ is gross yearly real earnings measured in DKK. The matrix $X$ contains a set of individual specific variables and $d_{j}$ are dummy variables for each education cell. The variables included in $X$ are years of education, age and age squared. We use age instead of experience because of the exogenous nature of age. The education fixed-effects $\alpha_{j}$ are included in order to control for the effect of omitted variables that may bias our measures of risk and skewness within an education cell. We use the estimated residuals to compute the different measures of R and K. As in McGoldrick (1995), and Hartog, Plug, Diaz-Serrano, and Vieira (2003) we first consider the following measures for $\mathrm{R}$ and $\mathrm{K}$

\footnotetext{
${ }^{7}$ Hartog and Vijverberg (2002) provide also structural equation estimates allowing for different assumptions on the utility function and for non-normal errors. They show that our specification is a good approximation to a proper structural equation.
} 


$$
R_{j}^{(1)}=\frac{1}{N_{j}} \sum_{i}\left(e_{i j}-\bar{e}_{j}\right)^{2} \quad K_{j}^{(1)}=\frac{1}{N_{j}} \sum_{i}\left(e_{i j}-\bar{e}_{j}\right)^{3}
$$

where $e_{i j}$ is the exponential of the estimated residuals $\varepsilon_{i j}$ in equation (7). In (8), R and $\mathrm{K}$ are simply estimated as the second and third moment of the distribution of $\exp \left(\varepsilon_{j}\right)$. In the second step we include estimated values for $\mathrm{R}$ and $\mathrm{K}$ in the following wage equation

$$
\ln Y_{i j}=X_{i} \beta+\pi R_{j}+\lambda K_{j}+\varepsilon_{i j}
$$

where we expect that $\pi>0$ and $\lambda<0$. Contrary to equation (7), in equation (9) we do not include dummies for education cells since R and K. are already fixed in a given education cell.

The second way to measure $\mathrm{R}$ and $\mathrm{K}$ we consider is directly taken from Hartog and Vijverberg (2002). These measures are derived from their theoretical model and are defined by the following expressions

$$
R_{j}^{(2)}=\frac{1}{N_{j}} \sum_{i}\left(\frac{Y_{i j}-\hat{Y}_{i j}}{\hat{Y}_{i j}}\right)^{2} \quad K_{j}^{(2)}=\frac{1}{N_{j}} \sum_{i}\left(\frac{Y_{i j}-\hat{Y}_{i j}}{\hat{Y}_{i j}}\right)^{3}
$$

where $\mathrm{Y}$ are the individual real gross yearly wages and

$$
\hat{Y}_{i j}=\exp \left(X_{i} \hat{\beta}+\frac{\hat{\sigma}_{j}^{2}}{2}\right)
$$

In expression (11), $\hat{\beta}$ is the estimated parameter vector of equation (7). This vector also includes the education cells fixed-effects. And $\hat{\sigma}_{j}^{2}$ is the estimated variance of the random disturbance term in equation (7) calculated over each education cell; with a log-normal distribution, (11) would be an exact expression for the mean.

$R^{(1)}$ and $K^{(1)}$ are the second and third moment of the exponential of the residuals, whereas $R^{(2)}$ and $K^{(2)}$ are the relative variance and skewness, which fit better to the theoretical values of $\sigma_{a}$ and $\kappa_{a}$ relative to the mean, as defined in expression (6) ${ }^{8}$. Although both ways to

\footnotetext{
${ }^{8}$ See Hartog and Vijverberg (2002) for more details on the properties of measures R and K defined in
} (10). 
measure $R$ and $K$ use different inputs, they provide similar outcomes. The coefficients of correlation between $R^{(1)}$ and $R^{(2)}$, and between $K^{(1)}$ and $K^{(2)}$ report values above 0,99 for the whole sample period (see table 5). In table 5 we also report their mean and the standard deviation. We remark that in egalitarian Denmark the mean risk and skewness and their variation are quite low compared to those observed in the US ${ }^{9}$. However relative to the means the standard deviations report sufficient variability to search for effects of $R$ and $K$ on wages. Another remarkable fact is the increasing pattern reported by the mean and the standard deviation of $R$ and $K$ throughout the whole sample period; this may be related to the aging of the sample or to secular trends ${ }^{10}$.

\section{Insert table 5}

Results on the cross-section estimation of equation (9) for each year using the annual measures of $\mathrm{R}$ and $\mathrm{K}$ (1984 to 2000) are drawn in Figure 1. Besides $R$ and $K$, in equation (9) we also include years of schooling, age, age squared, and dummies for occupation and industry. The patterns shown for $R^{(1)}$ and $R^{(2)}$, and for $K^{(1)}$ and $K^{(2)}$ are identically shaped, which should not be surprising given the similar distributions and almost perfect correlations between $R^{(1)}$ and $R^{(2)}$, and between $K^{(1)}$ and $K^{(2)}$ reported in table 5. As the theory predicts, for all years we estimate highly significant effects of both risk and skewness on wages and with the expected signs, except for 1989 when skewness reports a non-significant effect. Thus, the estimates confirm that educations with higher risk in earnings offer higher mean incomes, whereas in those with more positively skewed distributions wages are slightly depressed. Results drawn in Figure 1 are summarized in table 6. For instance, a one unit increase in $R^{(2)}$ in a given education cell raises wages a maximum around $81 \%$ (1986) and a minimum around $17 \%$ (1998), with a mean effect of some $45 \%$. A unit increase in $K^{(2)}$ depresses wages a maximum around $20 \%$ (1986) and a minimum around $0.6 \%$ (1999), with a mean effect of some $8 \%$.

Insert table 6

\footnotetext{
${ }^{9}$ Using the 1998 CPS data Hartog and Vijverberg (2002) report mean values around 0.6 and 3, and standard deviations of about 0.5 and 6 for estimated $\mathrm{R}$ and $\mathrm{K}$ respectively.

${ }^{10}$ We do not dig into this phenomenon since it is far from the objective of the present work, but we leave its exploration for further research.
} 
Although our cross section results are in accordance with what the theory predicts for each year of the sample period, such results are quite disperse. The dispersion in our results is due to the fact that $R$ and $K$ vary substantially over time; both variables display increasing mean and variance (see table 5) ${ }^{11}$. In table 7 and 8 we report the intertemporal correlations for $R$ and $K$.. Correlations between two consecutive years tend to be very high, 0.9 and above, however such correlations tend to decrease systematically as the temporal gap between $t$ and $t+s$ increases.

Insert table 7

Insert table 8

This evidence suggests that although systematic differences in $R$ and $K$ across education cells exist and are persistent throughout time, their annual measures are very variable. However, we think that educations differ in inherent, more structural levels of earnings variability, and that individuals tend to respond to the differences of a more long-run nature. Therefore, we believe that using a unique measure of $R$ and $K$ to estimate the effect of risk and skewness on wages in each separate cross-section is more appropriate, and it can provide more stable results. Thus, taking advantage of our long panel we propose now as alternative measures of $\mathrm{R}$ and $\mathrm{K}$ their mean values

$$
R_{j}^{(3)}=\frac{1}{T} \sum_{t=1}^{T} R_{j t}^{(1)} \quad K_{j}^{(3)}=\frac{1}{T} \sum_{t=1}^{T} K_{j t}^{(1)}
$$

and

$$
R_{j}^{(4)}=\frac{1}{T} \sum_{t=1}^{T} R_{j t}^{(2)} \quad K_{j}^{(4)}=\frac{1}{T} \sum_{t=1}^{T} K_{j t}^{(2)}
$$

Hence, we now use the same measure of $\mathrm{R}$ and $\mathrm{K}$ to estimate their effects on wages in each of our 17 cross-sections. By doing this we smooth possible error in the annual measures, so that we can look for a "cleaner" effect of $R$ and $K$ on wages. Results are drawn in figure 2 . The estimated effects are now more stable than before (note the difference in scales). The gap between the maximum and the minimum risk-premium and skewness-penalty have been reduced drastically relative to the estimates provided by $R^{(1)}, R^{(2)}, K^{(1)}$ and $K^{(2)}$. For

${ }^{11}$ It is important to remark that although $R$ and $K$ vary substantially over time, their distributions are very stable in the sense that the ratio between the standard deviation and the mean (CV) displays small variation over time. 
instance, now using expression (13), in an education cell where $R^{(4)}$ is one unit higher wages rise a maximum around 43\% (2000) and the minimum increase observed is around 20\% (1987), reducing the spread between maximum and minimum to about a third of its level using $R$ (2). An increase in one unit in $K^{(4)}$ causes a maximum depression in wages around 5\% (2000) and a minimum around 0.7\% (1987), cutting the spread in half. By using $R^{(4)}$ and $K^{(4)}$ the average effect on wages throughout the sample period are $28 \%$ and $-2.5 \%$, whereas by using $R^{(2)}$ and $K^{(2)}$ these average effects were $44.6 \%$ and $-6.3 \%$ respectively. The intertemporal standard deviation of the risk-premium falls from 0.2 when $R^{(2)}$ is used to 0.05 for $R^{(4)}$. Such a remarkable fall of the dispersion also holds between $K^{(2)}$ and $K^{(4)}$ (see table 6). By applying the measures of $R$ and $K$ defined in (12) and (13) we observe a substantial improvement estimating the risk-premium and the skewness-penalty on wages, since they are more stable and homogeneous throughout time. The standard deviation of $R^{(3)}, R^{(4)}, K^{(3)}$ and $K^{(4)}$ is four times smaller than for $R^{(1)}, R^{(2)}, K^{(1)}$ and $K^{(2)}$.

In future work we will dig deeper into the timing effects of compensation for earnings variability. For now, we just observe that the declining effects of $\mathrm{R}$ and $\mathrm{K}$ in the annual cross-sections may reflect a dominant settlement in early career years: over the sample period, the panel inevitable ages, and the early cross-sections are dominated by relatively inexperienced workers compensated for early earnings variability. The conceptual framework in section 3 pointed to supply reactions of entrants to educations and wage determination (per unit of human capital) when the entrants graduate. A relatively strong effect in early career years is compatible with this model. In later stages of the career other effects may become more important. However, precise testing requires a precise model of cohort and time effects and we will leave that for another occasion.

The empirical results provided in this subsection are in accordance with the previous empirical evidence, thus we add Denmark to the selected list of countries for which the effects of risk and skewness on wages have been tested. However, in contrast to the previous literature, we base our measures of risk and skewness just on education cells, and not on occupations. This is an important improvement, as an education once completed is given and cannot be undone by selective exits as is the case with occupation cells. ${ }^{12}$.Our

\footnotetext{
${ }^{12}$ McGoldrick (1995) uses occupation cells and cross-section data for the US data. Hartog, Plug, DiazSerrano and Vieira (2003) use occupation cells and cross-section data from Netherlands, Germany, Spain
} 
results are consistent, and at this point we can unambiguously confirm the existence of a compensating wage differentials for schooling risk in Denmark. However, there are still some issues related to the dynamics of earnings shocks and risk compensation that need to be disentangled. We face these issues in the next subsection.

\subsection{Permanent and transitory shocks in earnings}

One of the problems associated with using annual measures on $R$ and $K$ as commonly done in the literature, and as indeed we did in last subsection, is their sensitivity to measurement errors. Our 17 years panel allows us to look for a long-term measure of risk ${ }^{13}$, which averages the possible measurement errors affecting the annual measures of risk over time, as we did in the previous section. On the other hand, using a big panel as ours also allows to test for compensating wage differentials for schooling risk controlling for individual heterogeneity. Hence, shocks in earnings (residuals) can be decomposed into a permanent and a transitory component. In this subsection, we estimate a Mincer earnings equation using panel data estimation, and hence we decompose residuals between transitory and permanent shocks. We then calculate separate measures of risk and skewness for both permanent and transitory shocks, and we include them in the pooled cross-section Mincer equation. Now, the model we use in the first stage is a panel data model with fixed-effects for individuals and education cells. The model is the following

$$
\ln Y_{i j t}=X_{i j t} \beta+v_{i j t}
$$

where the subscript $i$ indicates individuals, and $j$ indicates the educational cell the individual belongs to. $Y$ is real gross yearly earnings, and $X$ is a set of explanatory variables. In equation (14) we decompose the disturbance term as

$$
v_{i j t}=u_{i}+\gamma_{j}+\varepsilon_{i t}
$$

where

and Portugal. And Hartog and Vijverberg (2002) use education-occupation cells and cross-section data for the US.

${ }^{13}$ Hartog and Vijverberg (2002) emphasise the necessity of such a long-term measure to test risk compensation in wages in a more appropriate way. 
$E\left(u_{i} u_{k}\right)=\left\{\begin{array}{ll}\sigma_{u}^{2} & i=k \\ 0 & i \neq k\end{array}, \quad E\left(\varepsilon_{i t} \varepsilon_{k s}\right)=\left\{\begin{array}{ll}\sigma_{\varepsilon}^{2} & i=k, t=s \\ 0 & \text { otherwise }\end{array}, \quad E\left(\gamma_{j} \gamma_{h}\right)= \begin{cases}\sigma_{\gamma}^{2} & j=h \\ 0 & j \neq h\end{cases}\right.\right.$

The residual component $u_{i}$ is the time-invariant individual effect, $\gamma_{j}$ is the time-invariant education cell effect, and $\varepsilon_{i t}$ is the time-variant residual effect. To our purpose controlling for heterogeneity across types of education is crucial. On one hand, this term picks up the effect of omitted variables that otherwise would "pollute" $\varepsilon_{i t}$, and hence also our measures of $R$ and $K$ on transitory shocks. And on the other hand, by considering $\gamma_{j}$ we ensure that total within-cell variance $\sigma^{2}=\sigma_{u}^{2}+\sigma_{\varepsilon}^{2}$ holds for each education cell, where $\sigma_{u}^{2}$ is the variance of the permanent shocks and $\sigma_{\varepsilon}^{2}$ is the variance of the transitory shocks. It allow us to get consistent estimates of the variance of the transitory shocks in earnings for each education cell $\sigma_{\varepsilon(j)}^{2}$. We estimate $\gamma_{j}$ by considering dummies for each education cell. To estimate model (14) we use the unbalanced panel design described in section 4. In order to isolate the time-invariant education effects $\gamma_{j}$, we include dummies for each education cell, thus they are added to the set of explanatory variables in $X$ (years of schooling, age and age squared).

Once model (14) is estimated, we compute $R$ and $K$ separately for the exponential of the permanent shocks $u_{i}$ and the transitory shocks $\varepsilon_{i t}$, and we include them in earnings equation (9). To estimate model (14) we restrict the sample period from 1985 to 1999, whereas we leave the samples corresponding to the first (1984) and the last (2000) year of our sample period to estimate equation (9). Define $\alpha_{i}=\exp \left(u_{i}\right)$ and $e_{i t}=\exp \left(\varepsilon_{i t}\right)$, hence $R$ and $K$ for the permanent shocks in earnings are computed as

$$
R_{j}^{p}=\frac{1}{N_{j}} \sum_{i=1}^{N_{j}}\left(\alpha_{i j}-\bar{\alpha}_{j}\right)^{2} \quad K_{j}^{p}=\frac{1}{N_{j}} \sum_{i=1}^{N_{j}}\left(\alpha_{i j}-\bar{\alpha}_{j}\right)^{3}
$$

and for the transitory shocks

$$
R_{j}^{a}=\frac{1}{T} \frac{1}{N_{j}} \sum_{t=1}^{T} \sum_{i=1}^{N_{j}}\left(e_{i j t}-\bar{e}_{j t}\right)^{2} \quad K_{j}^{a}=\frac{1}{T} \frac{1}{N_{j}} \sum_{t=1}^{T} \sum_{i=1}^{N_{j}}\left(e_{i j t}-\bar{e}_{j t}\right)^{3}
$$


where in both (16) and (17) the subscript $j$ indicates the education cell the individual belongs to ${ }^{14}$. Notice that in (17) $R$ and $K$ are somewhat of a longitudinal schooling risk and skewness. Controlling for education cells fixed effects implies that $E\left(\varepsilon_{j}\right)=0$ but $E\left(\varepsilon_{j t}\right) \neq 0$ since we do not control for time-specific effects. This is the reason $E\left(\varepsilon_{j t}\right)$ enters in measures (17). In table 9 we report the basic results of the panel data estimation of equation (14)-(15). Table 10 reports some summary statistics on the distributions of $R^{p}, K^{p}, R^{a}$ and $K^{a .}$ These statistics reveal that once more $R$ and $K$ display sufficient variation across education types to look for effects on wages. Our first stage regression indicates that the variance of the permanent shock is much larger than the variance of the transitory shock. This is similar to what Chen (2003) reports for the United States ${ }^{15}$. However, if we group the variances by education, we find that the average value of risk is smaller for permanent shocks than for transitory shocks, while the reverse holds for skewness.

Insert table 9

Insert table 10

As we mentioned previously, one of the roles of the education time invariant effects in expression (15) is to control for the potentially devastating effect of omitted variables, which could bias the estimates of $R^{p}, K^{p}, R^{a}$ and $K^{a}$., In the second stage estimation, we cannot include fixed education effects. However, we can test whether $\mathrm{R}$ and $\mathrm{K}$ just pick up fixed effects, and possibly represent something else than earnings variability by regressing the time-invariant education effects on $R$ and $K: \gamma_{j}=\delta R_{j}+\eta K_{j}+\varsigma_{j}$. If $R$ and $K$ just represent fixed effects we would find $\pi=0$ and $\lambda=0$. Results reported in table 11 confirms the absence of this type of bias in $R^{p}, K^{p}, R^{a}$ and $K^{a}$.

\section{Insert table 11}

Insert table 12

\footnotetext{
${ }^{14}$ We only use one specification for $R(K)$, as table 5 shows perfect correlation between definitions (8) and (10)

${ }^{15}$ In the literature we can find some evidence on the variance of the permanent and transitory shocks in earnings by education levels (see e.g. Olson, White and Shefrin, 1979). However, there is no evidence about these shocks using detailed education types as we do here. Thus, we cannot contrast our results for Denmark extensively with those found in other countries. Alvarez, Browning and Ejrnaes (2003) provide a detailed analysis of patterns of individual earnings residuals in Denmark and find a large amount of individual heterogeneity in parameters for residual structures. Their approach is much too refined for our purpose; and certainly one could not expect compensation for all such heterogeneity.
} 
Estimations on equation (9) using $R^{p}, K^{p}, R^{a}$ and $K^{a}$ are reported in table 12 . Model 1 and 2 estimate risk-premium and skewness affection separately for permanent and transitory shocks, whereas model 3 includes simultaneously $R$ and $K$ of transitory and permanent shocks. We find that in both years 1984 and 2000, our measures of risk and skewness for transitory and permanent shocks in earnings are significant and with the expected signs. This significance of $R$ and $K$ in both years separated by so wide an interval confirms that our findings are quite stable. Thus, they also confirm that risk is an intrinsic long-run feature of the human capital investments. For instance, taking the results in 2000 for model 1 and 2, we estimate that a one percent increase in risk is associated with $0.06 \%$ higher earnings when it comes from permanent shocks, and $0.19 \%$ higher earnings when it comes from transitory shocks. The effects of skewness for both types of shocks display a very similar intensity, and depression in wages are around $0.005 \%$ for both types of shocks. In model 3, all the effects are also very significant but with a small fall in their intensity, however these latter results have to be taken with caution due to the correlations between $R^{p}, K^{p}, R^{a}$ and $K^{a}$, see table $13 .{ }^{16}$ The fact that the two types of variability are correlated may be seen as a further indication that the permanent component is not just individual heterogeneity. Why would educations with a high level of individual heterogeneity (e.g. ability) systematically also be characterized by a high level of transitory risk? It is more plausible that the high level of correlation reflects that some educations are affected by both permanent income shocks, for instance the scarring effect of graduating in a recession, and transitory business cycle effects on earnings.

Insert table 13

Our results on compensating wage differentials for schooling risk reveal that transitory shocks in earnings play a more important role than permanent shocks. Permanent variability is less compensated for transitory shocks, which means that those shocks are partly associated with individual heterogeneity or ability. To the extent that this information is better known by an individual entering an education than the future transitory shocks, the required compensation for such type of risk should be smaller. Hence, the result of a smaller compensation for permanents shocks is consistent with individuals being better informed on

\footnotetext{
${ }^{16}$ Using a rule of thumb that the correlation between regressors should not exceed 0.9 , only the correlation between permanent risk and skewness constitutes a serious multicollinearity problem.
} 
permanent shocks, as they contain individual heterogeneity on which individuals are better informed than the researcher.

\subsection{Earnings mobility and transitory risk}

Both in this paper and in earlier papers, we have established a premium on wages to compensate for the differential earnings risk associated with different educations. To measure earnings risk, we calculated statistics from earnings function residuals grouped by education. Thus we are vulnerable to the critique that such measures do not adequately measure risk. To meet this critique, we now deal with risk measures based on earnings mobility. We argue that the extent of movement of individuals through the earnings distribution is a good measure of transitory risk. In this subsection we use two different types of earnings mobility measures. The first set is based on earnings time-dependence (coefficient of rank correlation over time and minus-chi squared statistic), and the second one is based on individual earnings positional movement (quantile mobility ratio and percapita quantile movement). Define $e_{i t}=\exp \left(\varepsilon_{i t}\right)$, where $\varepsilon_{i t}$ are the transitory shocks in earnings estimated from equation (14). We compute earnings mobility with a time gap of 5 years, 1985-1990, 1986-1991, and so on. The definition of the selected mobility measures applied over $e_{i t}$ are:

\section{A. Time-dependence measures}

A1. We define the coefficient of rank correlation $(\rho)$ as

$$
\rho_{j}(t, t+5)=1-\frac{6 \sum_{i=1}^{N_{j}}\left[r_{i j}(t)-r_{i j}(t+5)\right]^{2}}{N_{j}\left(N_{j}^{2}-1\right)}
$$

where the subscript $j$ denotes the education cell the individual belongs to, $r_{i j}(t)$ is the individual's ranking position in the transitory earnings distribution at year $\mathrm{t}$, and $r_{i j}(t+5)$ is the individual's ranking position at year $t+5$. The rank correlation determines timedependence, so that we take as time-independence $1-\rho_{j}$. After calculating the $T-5$ possible rank correlations for all our sample period we average them throughout time for each education cell 


$$
\frac{1}{T-5} \sum_{t=1}^{T-5}\left[1-\rho_{j}(t, t+5)\right]
$$

Expression (19) increases with earnings mobility: a higher value represents greater earnings risk, as the ranking in a given year has less predictive power for the ranking five years later.

A2. The minus chi-squared statistic is defined as

$$
\chi_{j}^{2}(t, t+5)=\sum_{k \neq l} \frac{\left(p_{k, l}-0.1\right)^{2}}{0.1}
$$

Where $p_{k, l}$ is the probability to move from quantile $k$ in year $t$ to quantile $l$ in year $t+5$, and being $k \neq l$. To estimate $p_{k, l}$ we use a quintile transition matrix between $t$ and $t+5$, averaged throughout time

$$
\frac{1}{T-5} \sum_{t=1}^{T-5}-\chi_{j}^{2}(t, t+5)
$$

In (21) we change the sign in order to reflect time-independence. Thus, the coefficient rises with earnings mobility: a higher value represents a higher risk, as there is more movement between the quantiles of the distribution.

\section{B. Positional mobility measures}

B1. We define the quantile mobility ratio $Q_{k \neq t}(t, t+5)=1-Q_{k=l}(t, t+5)$, which is computed by a quantile transition matrix on earnings transitory shocks, as the fraction of individuals that do not remain in the same quantile between period $t$ and $t+5$. This index reflects instability. We distinguish between upward fluctuations $Q_{k<l}(t, t+5)$ and downward fluctuations $Q_{k>l}(t, t+5)$, where $k$ is the quintile where the individual is allocated in year $t$, and $l$ is the same concept for year $t+5$. Once all the transition matrixes have been computed for each education cell we average these indexes throughout time. We use as quantiles the deciles and quartiles.

B2. We define the per capita quantile mobility as

$$
\frac{1}{T-5} \sum_{t=1}^{T-5} \sum_{i=1}^{N_{j}} \frac{\left|Q_{i j}(t)-Q_{i j}(t+5)\right|}{N_{j}}
$$


Where $Q_{i j}(t)$ is the quantile of the earnings distribution where the individual is located in year $t$, and $Q_{i j}(t+5)$ is his quantile location in year $t+5$. We compute these indices by each education cell and average them over time. We use deciles and the index rises with earnings mobility.

In this subsection we follow the same strategy as before. Once all these movement measures on $e_{i j}$ have been computed for each education cell, we include each of them separately in a Mincer wage equation to test for compensating wage differentials for schooling risk. To compute transition matrixes and intertemporal rankings on $e_{i t}$ we use the panel covering the period 1995-1999, whereas to look for risk compensation we use again the first (1984) and last (2000) of our panel. As we mention above, the mobility and time-dependence measures used here are averaged over time. The results of the augmented Mincer equations are reported in table 13. Besides the earnings mobility measure, the earnings equations also include years of schooling, age, age squared, and dummies for occupation and industry. To make the results comparable we calculate the risk-wage elasticity for each mobility measure.

Insert table 14

To make our results in accordance with theory, all coefficients should be positive, except those for immobility. Note first of all that all our new measures, with very similar magnitudes in both years 1984 and 2000. For instance, concerning the results in 2000, one percent increase in the rank correlation variable in a given education cell rises wages about $0.07 \%$, whereas for the minus chi-squared and per-capita decile movement statistic such increment in wages is about $0.13 \%$ and $0.005 \%$. The theoretical predictions are supported for the measures based on rank correlation, immobility (quartiles and deciles) and per capita decile movement. Disturbing results derive from the distinction between upward and downward movement: one would have expected the signs to be reversed, as downward movement is generally considered as undesirable and upward movement may be hailed as a boon. The negative sign for the chi-squared measure is also disturbing. These results necessitate further reflection on the extent to which they are damaging to the thesis that the labour market provides compensation for wage risk. 


\section{Conclusions}

In this paper we contribute with new empirical evidence to the emerging literature on risk compensation in wages. To do this we use a 17 years panel containing $10 \%$ of the Danish population, and with a very detailed description of the educational attainment of the Danes. The qualities of our data set allow an in-depth analysis of the intrinsic return-risk trade-off associated with schooling choices. Our main contribution relative to the previous literature is to focus on two aspects. First, we base our estimations on compensating wage differentials on risk measures that employ education cells only, whereas the previous evidence also relies on occupation cells. And second, we incorporate an intertemporal dimension to the post-schooling risks. We are able to distinguish transitory and permanent earnings risk. We find that both permanent and transitory risk are associated with compensationg differentials, but that transitory shocks in earnings is much more relevant for compensating wage differentials than the permanent shocks. Encouraged by this latter result and given the dynamic nature of the transitory shocks in earnings, we also experiment with tests of risk compensation using new measures of risk based on fluctuations in transitory earnings. So far, we find mixed results: support but also rejections.

The new dynamic dimension introduced here fills a gap that previous evidence could not cover. We have experimented with permanent measures of risk rather than only contemporaneous ones. Clearly, these new permanent measures based on panel data catch the intrinsic long-run feature of the post-schooling risk and the required compensation for it. Our results are mostly in accordance with what theory predicts, though not for all risk measures. From our results we can derive some important implications. First, while some previous literature has revealed the important role of the length of education in the riskreturn trade-off, we find that not only the length but also the type of education plays a crucial role in this sense. And second, more risk-averse individuals facing a lower degree of risk will experience lower wage growth or even wage stagnation if they display strong preference for positively skewed wage distributions.

This horizontal dimension in the schooling choices we introduce here should be taken in to account for a proper research on individuals' curricula design and their returns. Hence, further research in this line is encouraged. Immediate extensions of our research would be to allow for selective choice of educations and test whether this is as important as many 
believe, and to allow for the drop-out risk. There are also many new fields in this area waiting to be ploughed. 


\section{References}

Alvarez, J.; M. Browning and M. Ejrnaes (2002): “Modelling Income Processes with lots of Heterogeneity”, Working Paper, University of Copenhagen.

Belzil, C. and J. Hansen (2002): “Earnings dispersion, risk aversion and education, IZA Discussion Paper, \#513, Bonn.

Chen, S. (2001): “Is Investing in College Education Risky?”, Discussion Paper, State University of New York at Albany.

Christiansen, C. and H.S. Nielsen (2002): “The Educational Asset Market: a Finance Perspective on Human Capital Investment”, ASB Working Paper, \#02-10, Aarhus.

Diaz-Serrano, L. (2001): Human capital, progressive taxation and risk aversion, Ph. D dissertation, Universitat Rovira i Virgili, Tarragona.

Eaton, J. and H.S. Rosen (1980): “Taxation, Human Capital and Uncertainty”, American Economic Review, 70 (4), pp. 705-716.

Feinberg, R. (1981): “Earnings-Risk as a Compensating Differentials”, Southern Economic Journal, 48, pp. 156-63.

Harmon, C.; V. Hogan and I. Walker (2003): "Dispersion in the Economic Return to Schooling”, Labour Economics, 10(2), pp. 205-14.

Hartog, J. and L. Diaz-Serrano (2002): "Earnings Risk and Demand for Higher Education: A Cross-Section Test for Spain”, IZA Discussion Paper, \#641, Bonn.

Hartog, J. and W.P.M. Vijverberg (2002): "Do Wages Really Compensate for Risk Aversion and Skewness Affection?”, IZA Discussion Paper, \#426, Bonn.

Hartog, J.; E. Plug, L. Diaz-Serrano and J.A.C Vieira (2003): "Risk Compensation in Wages: a Replication”, Empirical Economics, 28, pp. 639-47.

Hogan, V. and I. Walker (2001): “Education choice under uncertainty”, Working Paper University College Dublin/University of Warwick.

King, A.G. (1974): “Occupational Choice, Risk Aversion, and Wealth”. Industrial and Labor Relations Review, 27(4), pp. 586-96.

Kodde, D.A. (1986): “Uncertainty and the Demand for Education”, Review of Economics and Statistics, 68(3), pp. 460-67.

Levhari, D. and Y. Weiss (1974): “The Effect of Risk on the Investment in Human Capital”, American Economic Review, 64(6), pp. 950-63.

Low, S. and M.B. Ormiston (1991): "Stochastic Earnings Functions, Risk, and the Rate of Return to Schooling”, Southern Economic Journal, 57(4), 1124-32. 
McGoldrick, K. (1995): “Do Women Receive Compensating Wages for Earnings Uncertainty?”, Southern Economic Journal, 62, pp. 210-22.

McGoldrick, K. and J. Robst (1996): "The Effect of Worker Mobility on Compensating wages for Earnings Risk”, Applied Economics, 28, pp. 221-32.

Olson, L.; H. White and H.M. Shefrin (1979): "Optimal Investment in Schooling When Incomes Are Risky”, Journal of Political Economy, 87(3), pp. 522-39.

Pereira, P.T. and P.S. Martins (2002): "Is There a Return-Risk Link in Education?”, Economics Letters, 75(1), pp. 31-37.

Pratt, (1964): “Risk Aversion in the Small and in the Large”, Econometrica, 32, pp. 122-36.

Tsiang, S.C. (1974): "The Rationale of the Mean-Standard Deviation Analysis, Skewness Preference, and the Demand for Money”, American Economic Review, 64(3), 354371.

Weiss, Y. (1972): “The Risk Element in Occupational and Educational Choices”, Journal of Political Economy, 80(6), pp. 1203-13.

Williams, J. (1979): "Uncertainty and the Accumulation of Human Capital over the Lifecycle”, Journal of Business, 52(4), pp. 521-48. 


\section{Annex of tables and figures}

Table1: Description of the education cells (Gross yearly real wages - averaged by education cell and over time 1984-2000)

\begin{tabular}{|c|c|c|c|c|c|c|c|c|}
\hline \multirow{2}{*}{$\begin{array}{l}\begin{array}{l}\text { Level of } \\
\text { education }\end{array} \\
\text { Primary }\end{array}$} & \multirow{2}{*}{$\begin{array}{l}\text { Type of education } \\
\text { Basic School, } 7 \text { years }\end{array}$} & \multirow{2}{*}{$\begin{array}{c}\begin{array}{c}\text { Years } \\
\text { school }\end{array} \\
7\end{array}$} & \multicolumn{2}{|c|}{$\begin{array}{l}\text { Sample } \\
\text { size Mean }\end{array}$} & \multirow{2}{*}{$\begin{array}{r}\text { Varian. } \\
0.076\end{array}$} & \multirow{2}{*}{$\begin{array}{r}\text { Skew. } \\
0.531\end{array}$} & \multirow{2}{*}{$\begin{array}{r}\text { Min. } \\
11.589\end{array}$} & \multirow{2}{*}{$\begin{array}{r}\text { Max. } \\
14.709\end{array}$} \\
\hline & & & 4779 & 12.413 & & & & \\
\hline & Basic School, 9 years & 9 & 2260 & 12.501 & 0.110 & 0.861 & 11.592 & 14.785 \\
\hline \multirow[t]{2}{*}{ High school } & Preparatory School & 10 & 786 & 12.708 & 0.184 & 0.386 & 11.603 & 14.599 \\
\hline & High School & 12 & 41 & 12.464 & 0.138 & 0.621 & 11.704 & 13.448 \\
\hline \multirow{32}{*}{$\begin{array}{l}\text { Vocational } \\
\text { training }\end{array}$} & Appr. General Business & 12 & 1922 & 12.562 & 0.119 & 0.886 & 11.603 & 14.593 \\
\hline & Appr. Shop Assistant & 12 & 167 & 12.580 & 0.112 & 0.941 & 11.680 & 13.970 \\
\hline & Appr. Wholesale Shop Assistant & 12 & 1087 & 12.692 & 0.122 & 0.652 & 11.608 & 14.335 \\
\hline & Appr. Office Clerk & 12 & 685 & 12.781 & 0.090 & 0.572 & 11.671 & 14.453 \\
\hline & Appr. Bank Office Clerk & 12 & 90 & 12.877 & 0.113 & -0.213 & 11.854 & 13.915 \\
\hline & Appr. IT Office Clerk & 12 & 518 & 12.396 & 0.080 & 0.115 & 11.601 & 13.642 \\
\hline & Appr. Builder & 12 & 899 & 12.445 & 0.070 & 0.372 & 11.604 & 13.927 \\
\hline & Appr. Carpenter & 12 & 613 & 12.425 & 0.063 & 0.350 & 11.611 & 13.635 \\
\hline & Appr. Joiner & 12 & 336 & 12.495 & 0.063 & 0.118 & 11.631 & 13.421 \\
\hline & Appr. Plumbing & 12 & 490 & 12.421 & 0.066 & 0.285 & 11.618 & 13.585 \\
\hline & Appr. Painter & 12 & 700 & 12.541 & 0.061 & 0.126 & 11.633 & 13.626 \\
\hline & Appr. Electrician & 12 & 84 & 12.420 & 0.104 & 1.603 & 11.647 & 14.102 \\
\hline & Appr. Construction and Pavor & 12 & 1111 & 12.490 & 0.062 & 0.266 & 11.605 & 13.783 \\
\hline & Appr. Metal & 12 & 31 & 12.480 & 0.067 & -0.254 & 11.838 & 13.028 \\
\hline & Appr. Jeweller & 12 & 1368 & 12.535 & 0.070 & 0.588 & 11.606 & 13.918 \\
\hline & Appr. Fitter & 12 & 1616 & 12.490 & 0.067 & 0.483 & 11.605 & 14.104 \\
\hline & Appr. Mechanics & 12 & 314 & 12.663 & 0.095 & 0.190 & 11.688 & 13.652 \\
\hline & Appr. Electronics Mechanics & 12 & 49 & 12.563 & 0.058 & 0.878 & 12.067 & 13.377 \\
\hline & Appr. IT Mechanics & 12 & 98 & 12.432 & 0.092 & 1.029 & 11.666 & 13.832 \\
\hline & Appr. Misc. Iron, Metal & 12 & 484 & 12.718 & 0.087 & 0.207 & 11.639 & 14.047 \\
\hline & Appr. Graphic & 12 & 35 & 12.643 & 0.191 & 0.125 & 11.778 & 13.456 \\
\hline & Appr. Photography & 12 & 275 & 12.524 & 0.104 & 0.391 & 11.615 & 13.821 \\
\hline & Appr. Misc. Technical & 12 & 145 & 12.537 & 0.116 & 0.497 & 11.668 & 13.732 \\
\hline & Appr. Service & 12 & 426 & 12.516 & 0.079 & 0.360 & 11.647 & 13.716 \\
\hline & Appr. Dairyman, Butcher & 12 & 236 & 12.443 & 0.070 & 0.572 & 11.675 & 13.698 \\
\hline & Appr. Baker & 12 & 263 & 12.491 & 0.092 & 0.180 & 11.623 & 13.587 \\
\hline & Appr. Cook, Waiter and Food & 12 & 123 & 12.375 & 0.082 & -0.226 & 11.646 & 13.094 \\
\hline & Appr. Agriculture & 12 & 147 & 12.416 & 0.052 & -0.205 & 11.676 & 13.048 \\
\hline & Appr. Gardener and Forestry & 12 & 80 & 12.433 & 0.129 & 0.581 & 11.666 & 13.495 \\
\hline & Appr. Fishing and Agriculture & 12 & 93 & 12.506 & 0.089 & 0.558 & 11.698 & 13.551 \\
\hline & Appr. Transport & 12 & 77 & 12.396 & 0.050 & 0.221 & 11.747 & 13.137 \\
\hline & Appr. Dental Assistant and Health Care & 12 & 42 & 12.614 & 0.099 & -0.069 & 11.830 & 13.329 \\
\hline \multirow{7}{*}{$\begin{array}{l}\text { Post } \\
\text { secondary } \\
\text { (non } \\
\text { university) }\end{array}$} & SCHE Education and Language & 14 & 57 & 12.629 & 0.134 & 0.629 & 11.833 & 13.654 \\
\hline & SCHE Music, Aesthetics and Social Sc. & 14 & 63 & 12.637 & 0.114 & 0.366 & 11.850 & 13.618 \\
\hline & SCHE Laboritry Assistant and Graphic & 14 & 736 & 12.642 & 0.088 & 0.050 & 11.621 & 14.086 \\
\hline & SCHE Mish. Technical & 14 & 43 & 12.697 & 0.108 & 0.817 & 11.999 & 13.743 \\
\hline & SCHE Food & 14 & 54 & 12.506 & 0.075 & -0.110 & 11.745 & 13.245 \\
\hline & SCHE Agriculture, Fishing and Transport & 14 & 48 & 12.518 & 0.073 & 0.827 & 11.843 & 13.446 \\
\hline & SCHE Miscelaneous & 14 & 48 & 12.476 & 0.175 & 1.487 & 11.938 & 13.680 \\
\hline
\end{tabular}


Table 1: continuation

\begin{tabular}{|c|c|c|c|c|c|c|c|c|}
\hline $\begin{array}{l}\text { Level of } \\
\text { education }\end{array}$ & Type of education & $\begin{array}{l}\text { Years } \\
\text { school }\end{array}$ & $\begin{array}{r}\text { Sample } \\
\text { Size }\end{array}$ & Mean & Varian. & Skew. & Min. & Max. \\
\hline & SCHE Health Care & 14 & 324 & 12.602 & 0.025 & 0.687 & 11.865 & 13.499 \\
\hline & SCHE Police, Warder & 14 & 39 & 12.678 & 0.042 & 1.439 & 12.400 & 13.252 \\
\hline & SCHE Armed Forces & 14 & 401 & 12.474 & 0.051 & -0.065 & 11.627 & 13.335 \\
\hline \multirow{11}{*}{$\begin{array}{l}\text { Higher } \\
\text { education } \\
\text { short cycle }\end{array}$} & MCHE Educator & 16 & 1382 & 12.613 & 0.037 & 0.355 & 11.628 & 13.777 \\
\hline & MCHE School or Needlework Teacher & 16 & 91 & 12.911 & 0.100 & 0.531 & 11.930 & 14.276 \\
\hline & MCHE Journalism & 16 & 54 & 12.542 & 0.060 & -0.433 & 11.760 & 13.168 \\
\hline & MCHE Business Language & 16 & 83 & 12.511 & 0.053 & -0.222 & 11.755 & 13.115 \\
\hline & MCHE Social Worker & 16 & 789 & 12.992 & 0.094 & 0.264 & 11.726 & 14.526 \\
\hline & MCHE Engineering & 16 & 525 & 12.828 & 0.109 & -0.084 & 11.676 & 14.230 \\
\hline & MCHE Misc. Technical & 16 & 370 & 12.757 & 0.075 & -0.214 & 11.683 & 13.747 \\
\hline & MCHE Agriculture, Fishing and Transport & 16 & 69 & 12.555 & 0.048 & 0.251 & 11.904 & 13.236 \\
\hline & MCHE Midwife, Radiologist, Nursery, & 16 & & & & & & \\
\hline & Physiotherapist etc. & & 114 & 13.075 & 0.258 & 0.697 & 11.833 & 14.907 \\
\hline & BA Natural Sciences, Humanities and & 16 & 44 & 736 & ר900 & & 842 & \\
\hline \multirow{18}{*}{$\begin{array}{l}\text { Higher } \\
\text { education } \\
\text { long cycle }\end{array}$} & MA Education and Humanities & 18 & 63 & 12.749 & 0.073 & -0.226 & 11.862 & 13.530 \\
\hline & MA Theology & 18 & 110 & 12.722 & 0.086 & -0.656 & 11.785 & 13.423 \\
\hline & MA History, Archaeology & 18 & 66 & 12.658 & 0.108 & -1.004 & 11.701 & 13.248 \\
\hline & MA Literature, Arts, Music, Aesthetics & 18 & 154 & 12.752 & 0.082 & -0.616 & 11.757 & 13.675 \\
\hline & MA Business Language & 18 & 47 & 12.982 & 0.129 & 0.610 & 12.082 & 14.051 \\
\hline & MSc IT, Math, Statistics & 18 & 81 & 12.939 & 0.102 & -0.036 & 11.833 & 14.093 \\
\hline & MSc Physics, Astronomy, Chemestry & 18 & 118 & 12.780 & 0.086 & -0.085 & 11.764 & 13.832 \\
\hline & $\begin{array}{l}\text { MSc Geology, Geography, Biology, } \\
\text { Sports }\end{array}$ & 18 & 125 & 13.145 & 0.170 & 0.356 & 11.916 & \\
\hline & MSc Economics & 18 & 179 & 13.061 & 0.125 & 0.105 & 11.859 & 14.296 \\
\hline & MA Law (LLM) & 18 & 122 & 12.884 & 0.084 & -0.471 & 11.783 & 13.702 \\
\hline & MA Political Sciences, Sociology & 18 & 197 & 13.027 & 0.202 & 0.424 & 11.758 & 14.685 \\
\hline & MA Misc. Social Sciences & 18 & 303 & 13.091 & 0.123 & -0.198 & 11.761 & 14.488 \\
\hline & MSc Engineering & 18 & 176 & 12.752 & 0.092 & -0.724 & 11.677 & 13.642 \\
\hline & MA Architecture (MAA) & 18 & 84 & 12.872 & 0.084 & 0.374 & 11.907 & 14.005 \\
\hline & MA Food & 18 & 266 & 13.159 & 0.078 & -1.217 & 11.756 & 13.890 \\
\hline & Msc Medicine & 18 & 57 & 12.950 & 0.125 & -0.450 & 11.973 & 13.748 \\
\hline & MSc Dentistry, Pharmacy & 18 & 69 & 12.918 & 0.161 & 0.696 & 11.891 & 14.246 \\
\hline & Msc MA & 18 & 434 & 13.039 & 0.215 & 0.235 & 11.649 & 14.741 \\
\hline PhD & $\mathrm{PhD}$. & 20 & 102 & 13.046 & 0.096 & 0.192 & 12.042 & 13.993 \\
\hline
\end{tabular}

Table 2: Summary statistics on selected variables

\begin{tabular}{l|rrrr}
\hline \hline & \multicolumn{4}{|c}{ Standard } \\
& Mean & Deviation & Minimum & Maximum \\
\hline Log-wage & 12.586 & 0.354 & 11.561 & 15.633 \\
Years of schooling & 12.125 & 3.145 & 7 & 20 \\
Age & 42.882 & 5.769 & 30 & 56 \\
Age-squared & 1872,144 & 496,633 & 900 & 3136 \\
\hline \hline
\end{tabular}


Table 3: Description of the sample by birth cohorts

\begin{tabular}{|c|c|c|c|c|c|c|}
\hline \multirow{2}{*}{$\frac{\text { Birth year }}{1944}$} & \multicolumn{2}{|c|}{$\begin{array}{r}\text { Total Number } \\
\text { sample of years } \\
\text { size observed } \\
\end{array}$} & \multicolumn{2}{|c|}{$\begin{array}{l}\text { Sample } \\
\text { size percentage }\end{array}$} & \multirow{2}{*}{$\begin{array}{r}\text { Age in } \\
1984 \\
40\end{array}$} & \multirow{2}{*}{$\begin{array}{r}\text { Age in } \\
\mathbf{2 0 0 0} \\
56\end{array}$} \\
\hline & 3,332 & up to 9 & 882 & $26 \%$ & & \\
\hline & & 10 to 16 & 998 & $30 \%$ & & \\
\hline & & 17 & 1,452 & $44 \%$ & & \\
\hline \multirow[t]{3}{*}{1945} & 3,647 & up to 9 & 936 & $26 \%$ & 39 & 55 \\
\hline & & 10 to 16 & 1,107 & $30 \%$ & & \\
\hline & & 17 & 1,604 & $44 \%$ & & \\
\hline \multirow[t]{3}{*}{1946} & 3,866 & up to 9 & 1,008 & $26 \%$ & 38 & 54 \\
\hline & & 10 to 16 & 1,175 & $30 \%$ & & \\
\hline & & 17 & 1,683 & $44 \%$ & & \\
\hline \multirow[t]{3}{*}{1947} & 3,971 & up to 9 & 922 & $23 \%$ & 37 & 53 \\
\hline & & 10 to 16 & 1,232 & $31 \%$ & & \\
\hline & & 17 & 1,817 & $46 \%$ & & \\
\hline \multirow[t]{3}{*}{1948} & 3,903 & up to 9 & 916 & $23 \%$ & 36 & 52 \\
\hline & & 10 to 16 & 1,227 & $31 \%$ & & \\
\hline & & 17 & 1,760 & $45 \%$ & & \\
\hline \multirow[t]{3}{*}{1949} & 3,733 & up to 9 & 876 & $23 \%$ & 35 & 51 \\
\hline & & 10 to 16 & 1,198 & $32 \%$ & & \\
\hline & & 17 & 1,659 & $44 \%$ & & \\
\hline \multirow[t]{3}{*}{1950} & 3,610 & up to 9 & 804 & $22 \%$ & 34 & 50 \\
\hline & & 10 to 16 & 1,147 & $32 \%$ & & \\
\hline & & 17 & 1,659 & $46 \%$ & & \\
\hline \multirow[t]{3}{*}{1951} & 3,673 & up to 9 & 846 & $23 \%$ & 33 & 49 \\
\hline & & 10 to 16 & 1,168 & $32 \%$ & & \\
\hline & & 17 & 1,659 & $45 \%$ & & \\
\hline \multirow[t]{3}{*}{1952} & 3,619 & up to 9 & 800 & $22 \%$ & 32 & 48 \\
\hline & & 10 to 16 & 1,160 & $32 \%$ & & \\
\hline & & 17 & 1,659 & $46 \%$ & & \\
\hline \multirow[t]{3}{*}{1953} & 3,654 & up to 9 & 858 & $23 \%$ & 31 & 47 \\
\hline & & 10 to 16 & 1,137 & $31 \%$ & & \\
\hline & & 17 & 1,659 & $45 \%$ & & \\
\hline \multirow[t]{3}{*}{1954} & 3,662 & up to 9 & 844 & $23 \%$ & 30 & 46 \\
\hline & & 10 to 16 & 1,159 & $32 \%$ & & \\
\hline & & 17 & 1,659 & $45 \%$ & & \\
\hline \multirow[t]{3}{*}{ All Cohorts } & 40,670 & up to 9 & 9,692 & $24 \%$ & 30 & 56 \\
\hline & & 10 to 16 & 12,708 & $31 \%$ & & \\
\hline & & 17 & 18,270 & $45 \%$ & & \\
\hline
\end{tabular}


Table 4: Description of the sample by year (Y: real log-wage)

\begin{tabular}{|c|c|c|c|c|c|c|c|c|c|c|c|c|c|}
\hline & \multicolumn{9}{|c|}{ Sample Analysis } & \multicolumn{4}{|c|}{ Individuals aged 30-56 } \\
\hline & & & balanced & I panel d & ign & & $\operatorname{anced} \mathbf{p}$ & anel des & & & & & \\
\hline & & & Log gr & $\begin{array}{l}\text { oss yearl } \\
\text { earnings }\end{array}$ & labour & & $\begin{array}{r}\text { Log gro } \\
\mathrm{e}\end{array}$ & $\begin{array}{l}\text { ss yearl } \\
\text { arnings }\end{array}$ & labour & & Log gr & $\begin{array}{l}\text { ss yearly } \\
\text { arnings }\end{array}$ & labour \\
\hline Year & Sample Ages & $N$ & Mean & Var & Skewness & $N$ & Mean & Var & Skewness & $N$ & Mean & Var & Skewness \\
\hline 1984 & $30-40$ & 31,504 & 12.49 & 0.095 & 0.532 & 17,713 & 12.52 & 0.074 & 0.708 & 62,913 & 12.49 & 0.111 & 0.585 \\
\hline 1985 & $31-41$ & 32,307 & 12.50 & 0.103 & 0.551 & 17,713 & 12.54 & 0.077 & 0.902 & 65,083 & 12.48 & 0.115 & 0.609 \\
\hline 1986 & $32-42$ & 32,540 & 12.53 & 0.105 & 0.626 & 17,713 & 12.57 & 0.079 & 0.996 & 66,906 & 12.51 & 0.114 & 0.599 \\
\hline 1987 & $33-43$ & 32,268 & 12.57 & 0.111 & 0.593 & 17,713 & 12.62 & 0.085 & 0.931 & 67,468 & 12.54 & 0.119 & 0.595 \\
\hline 1988 & $34-44$ & 31,432 & 12.59 & 0.111 & 0.652 & 17,713 & 12.64 & 0.088 & 0.952 & 67,599 & 12.56 & 0.119 & 0.586 \\
\hline 1989 & $35-45$ & 31,196 & 12.58 & 0.118 & 0.643 & 17,713 & 12.63 & 0.093 & 0.966 & 67,700 & 12.54 & 0.123 & 0.562 \\
\hline 1990 & $36-46$ & 30,723 & 12.59 & 0.120 & 0.698 & 17,713 & 12.63 & 0.097 & 0.985 & 68,040 & 12.54 & 0.126 & 0.578 \\
\hline 1991 & $37-47$ & 30,417 & 12.59 & 0.123 & 0.637 & 17,713 & 12.64 & 0.099 & 0.933 & 68,691 & 12.54 & 0.129 & 0.490 \\
\hline 1992 & $38-48$ & 30,130 & 12.60 & 0.125 & 0.628 & 17,713 & 12.65 & 0.100 & 0.971 & 69,278 & 12.55 & 0.129 & 0.464 \\
\hline 1993 & $39-49$ & 29,469 & 12.59 & 0.129 & 0.635 & 17,713 & 12.65 & 0.102 & 0.882 & 68,916 & 12.54 & 0.131 & 0.435 \\
\hline 1994 & $40-50$ & 29,745 & 12.61 & 0.135 & 0.671 & 17,713 & 12.67 & 0.106 & 1.000 & 70,066 & 12.56 & 0.131 & 0.534 \\
\hline 1995 & $41-51$ & 29,782 & 12.61 & 0.135 & 0.786 & 17,713 & 12.68 & 0.108 & 1.092 & 71,802 & 12.57 & 0.129 & 0.603 \\
\hline 1996 & $42-52$ & 29,656 & 12.62 & 0.137 & 0.764 & 17,713 & 12.68 & 0.109 & 1.083 & 72,531 & 12.57 & 0.131 & 0.604 \\
\hline 1997 & $43-53$ & 29,603 & 12.62 & 0.136 & 0.777 & 17,713 & 12.69 & 0.109 & 1.116 & 74,228 & 12.58 & 0.129 & 0.602 \\
\hline 1998 & $44-54$ & 29,586 & 12.63 & 0.142 & 0.817 & 17,713 & 12.69 & 0.115 & 1.121 & 76,496 & 12.59 & 0.134 & 0.642 \\
\hline 1999 & $45-55$ & 29,350 & 12.64 & 0.141 & 0.844 & 17,713 & 12.70 & 0.114 & 1.164 & 77,281 & 12.61 & 0.135 & 0.667 \\
\hline 2000 & $46-56$ & 29,225 & 12.63 & 0.143 & 0.875 & 17,713 & 12.70 & 0.117 & 1.129 & 77,839 & 12.61 & 0.137 & 0.726 \\
\hline 1984-2000 & $30-56$ & 518,933 & 12.586 & 0.1253 & 0.728 & 301,121 & 12.64 & 0.101 & 1.037 & $1,192,837$ & 12.55 & 0.128 & 0.592 \\
\hline
\end{tabular}


Table 5: Summary statistics for $\mathrm{R}^{(1)}, \mathrm{R}^{(2)}, \mathrm{K}^{(1)}$ and $\mathrm{K}^{(2)}$.

\begin{tabular}{l|c|c|cc|cc|cc|cc}
\hline \hline & \multicolumn{2}{|c|}{$\begin{array}{c}\text { Pearson } \\
\text { Correlation }\end{array}$} & \multicolumn{2}{c|}{$\mathbf{R}^{\mathbf{( 1 )}}$} & \multicolumn{2}{c|}{$\mathbf{R}^{(\mathbf{2})}$} & \multicolumn{3}{|c}{$\mathbf{K}^{(\mathbf{1})}$} & \multicolumn{2}{c}{$\mathbf{K}^{(\mathbf{2})}$} \\
\cline { 2 - 11 } & $\mathbf{R}^{(\mathbf{1})} \cdot \mathbf{R}^{(\mathbf{( 2 )}}$ & $\mathbf{K}^{(\mathbf{1})} \cdot \mathbf{K}^{\mathbf{( 2 )}}$ & Mean & S. D. & Mean & S. D. & Mean & S. D. & Mean & S. D. \\
\hline $\mathbf{1 9 8 4}$ & 0.999 & 0.999 & 0.103 & 0.075 & 0.094 & 0.063 & 0.127 & 0.265 & 0.108 & 0.210 \\
$\mathbf{1 9 8 5}$ & 0.999 & 0.999 & 0.106 & 0.068 & 0.097 & 0.058 & 0.121 & 0.219 & 0.103 & 0.178 \\
$\mathbf{1 9 8 6}$ & 0.999 & 0.998 & 0.114 & 0.078 & 0.103 & 0.066 & 0.147 & 0.288 & 0.123 & 0.226 \\
$\mathbf{1 9 8 7}$ & 0.999 & 0.998 & 0.117 & 0.077 & 0.105 & 0.064 & 0.143 & 0.273 & 0.119 & 0.214 \\
$\mathbf{1 9 8 8}$ & 0.999 & 0.998 & 0.117 & 0.077 & 0.106 & 0.064 & 0.146 & 0.263 & 0.122 & 0.204 \\
$\mathbf{1 9 8 9}$ & 0.999 & 0.998 & 0.119 & 0.075 & 0.107 & 0.062 & 0.136 & 0.245 & 0.113 & 0.188 \\
$\mathbf{1 9 9 0}$ & 0.999 & 0.999 & 0.122 & 0.091 & 0.109 & 0.074 & 0.165 & 0.443 & 0.135 & 0.326 \\
$\mathbf{1 9 9 1}$ & 0.999 & 0.999 & 0.122 & 0.088 & 0.109 & 0.073 & 0.160 & 0.408 & 0.133 & 0.313 \\
$\mathbf{1 9 9 2}$ & 0.999 & 0.996 & 0.130 & 0.102 & 0.116 & 0.082 & 0.202 & 0.487 & 0.165 & 0.363 \\
$\mathbf{1 9 9 3}$ & 0.999 & 0.999 & 0.137 & 0.117 & 0.121 & 0.093 & 0.244 & 0.655 & 0.196 & 0.489 \\
$\mathbf{1 9 9 4}$ & 0.999 & 0.999 & 0.150 & 0.142 & 0.132 & 0.112 & 0.310 & 1.140 & 0.241 & 0.805 \\
$\mathbf{1 9 9 5}$ & 0.999 & 0.998 & 0.155 & 0.137 & 0.137 & 0.110 & 0.341 & 1.068 & 0.270 & 0.772 \\
$\mathbf{1 9 9 6}$ & 0.996 & 0.996 & 0.160 & 0.145 & 0.139 & 0.113 & 0.352 & 1.148 & 0.276 & 0.820 \\
$\mathbf{1 9 9 7}$ & 0.997 & 0.998 & 0.160 & 0.151 & 0.139 & 0.114 & 0.325 & 1.159 & 0.249 & 0.790 \\
$\mathbf{1 9 9 8}$ & 0.998 & 0.997 & 0.164 & 0.141 & 0.144 & 0.110 & 0.350 & 0.987 & 0.276 & 0.692 \\
$\mathbf{1 9 9 9}$ & 0.998 & 1.000 & 0.170 & 0.151 & 0.150 & 0.126 & 0.677 & 3.467 & 0.549 & 2.797 \\
$\mathbf{2 0 0 0}$ & 0.998 & 0.997 & 0.179 & 0.128 & 0.157 & 0.105 & 0.433 & 0.878 & 0.353 & 0.701 \\
\hline \hline
\end{tabular}

Table 6: Summary of annual estimation of equation (9)

\begin{tabular}{l|rrrr}
\hline & Mean & Std. dev & Minimum & Maximum \\
\hline $\mathbf{R}^{(\mathbf{1})}$ & 0.3806 & 0.1659 & 0.1641 & 0.7043 \\
$\mathbf{K}^{(\mathbf{1})}$ & -0.0627 & 0.0534 & -0.1663 & -0.0051 \\
$\mathbf{R}^{(\mathbf{2})}$ & 0.4466 & 0.1977 & 0.1705 & 0.8132 \\
$\mathbf{K}^{(\mathbf{2})}$ & -0.0775 & 0.0672 & -0.2018 & -0.0067 \\
$\mathbf{R}^{(3)}$ & 0.2412 & 0.0479 & 0.1626 & 0.3755 \\
$\mathbf{K}^{(\mathbf{3})}$ & -0.0204 & 0.0106 & -0.0448 & -0.0067 \\
$\mathbf{R}^{(4)}$ & 0.2813 & 0.0551 & 0.1944 & 0.4368 \\
$\mathbf{K}^{(4)}$ & -0.0247 & 0.0126 & -0.0541 & -0.0089 \\
\hline Sample size & & & 94,000 & 106,000 \\
\hline \hline
\end{tabular}


Figure 1: Annual estimation of risk premium and skewness affection using annual measures

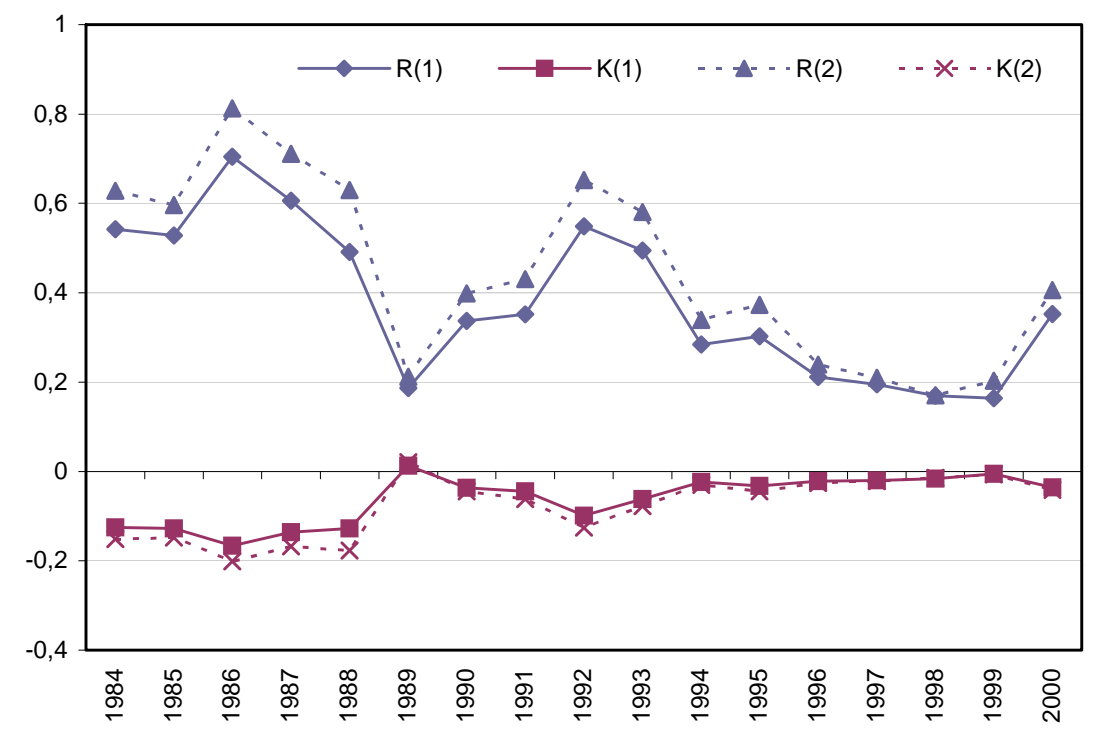

Figure 2: Annual estimation of risk premium and skewness affection using annual measures averaged over time.

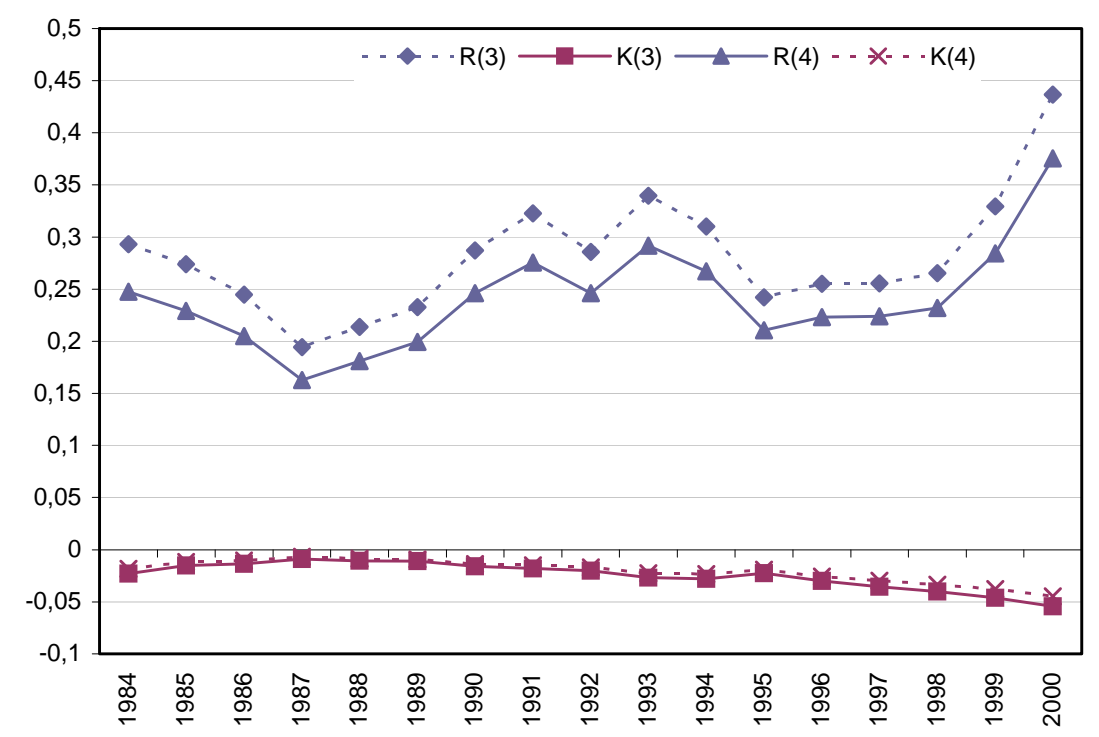


Table 7: Intertemporal correlations between $\mathrm{R}^{(1)}$ and $\mathrm{R}^{(2)}$

\begin{tabular}{|c|c|c|c|c|c|c|c|c|c|c|c|c|c|c|c|c|}
\hline & 1984 & 1985 & 1986 & 1987 & 1988 & 1989 & 1990 & 1991 & 1992 & 1993 & 1994 & 1995 & 1996 & 1997 & \begin{tabular}{|l|l|}
1998 \\
\end{tabular} & 1999 \\
\hline 1985 & 0.95 & & & & & & & & & & & & & & & \\
\hline 1986 & 0.95 & 0.96 & & & & & & & & & & & & & & \\
\hline 1987 & 0.88 & 0.89 & 0.93 & & & & & & & & & & & & & \\
\hline 1988 & 0.88 & 0.87 & 0.91 & 0.96 & & & & & & & & & & & & \\
\hline 1989 & 0.86 & 0.86 & 0.91 & 0.94 & 0.96 & & & & & & & & & & & \\
\hline 1990 & 0.88 & 0.84 & 0.88 & 0.90 & 0.91 & 0.94 & & & & & & & & & & \\
\hline 1991 & 0.85 & 0.80 & 0.86 & 0.92 & 0.91 & 0.94 & 0.96 & & & & & & & & & \\
\hline 1992 & 0.76 & 0.71 & 0.79 & 0.88 & 0.89 & 0.92 & 0.93 & 0.97 & & & & & & & & \\
\hline 1993 & 0.70 & 0.65 & 0.72 & 0.85 & 0.85 & 0.88 & 0.90 & 0.95 & 0.98 & & & & & & & \\
\hline 1994 & 0.74 & 0.68 & 0.75 & 0.82 & 0.85 & 0.88 & 0.93 & 0.94 & 0.96 & 0.96 & & & & & & \\
\hline 1995 & 0.73 & 0.69 & 0.75 & 0.80 & 0.84 & 0.86 & 0.91 & 0.90 & 0.92 & 0.91 & 0.97 & & & & & \\
\hline 1996 & 0.78 & 0.72 & 0.78 & 0.85 & 0.86 & 0.88 & 0.92 & 0.92 & 0.91 & 0.90 & 0.94 & 0.94 & & & & \\
\hline 1997 & 0.74 & 0.68 & 0.73 & 0.78 & 0.83 & 0.83 & 0.91 & 0.87 & 0.88 & 0.87 & 0.92 & 0.90 & 0.93 & & & \\
\hline 1998 & 0.77 & 0.73 & 0.76 & 0.82 & 0.85 & 0.84 & 0.91 & 0.89 & 0.86 & 0.84 & 0.90 & 0.88 & 0.90 & 0.94 & & \\
\hline 1999 & 0.59 & 0.59 & 0.55 & 0.53 & 0.56 & 0.58 & 0.58 & 0.56 & 0.53 & 0.49 & 0.54 & 0.56 & 0.56 & 0.61 & 0.66 & \\
\hline 2000 & 0.66 & 0.69 & 0.67 & 0.63 & 0.69 & 0.65 & 0.65 & 0.60 & 0.56 & 0.51 & 0.57 & 0.61 & 0.60 & 0.64 & 0.77 & 0.61 \\
\hline
\end{tabular}

Table 8: Intertemporal correlations between $\mathrm{K}^{(1)}$ and $\mathrm{K}^{(2)}$

\begin{tabular}{lllllllllllllllll|}
1984 & 1985 & 1986 & 1987 & 1988 & 1989 & 1990 & 1991 & 1992 & 1993 & 1994 & 1995 & 1996 & 1997 & 1998 & 1999
\end{tabular}

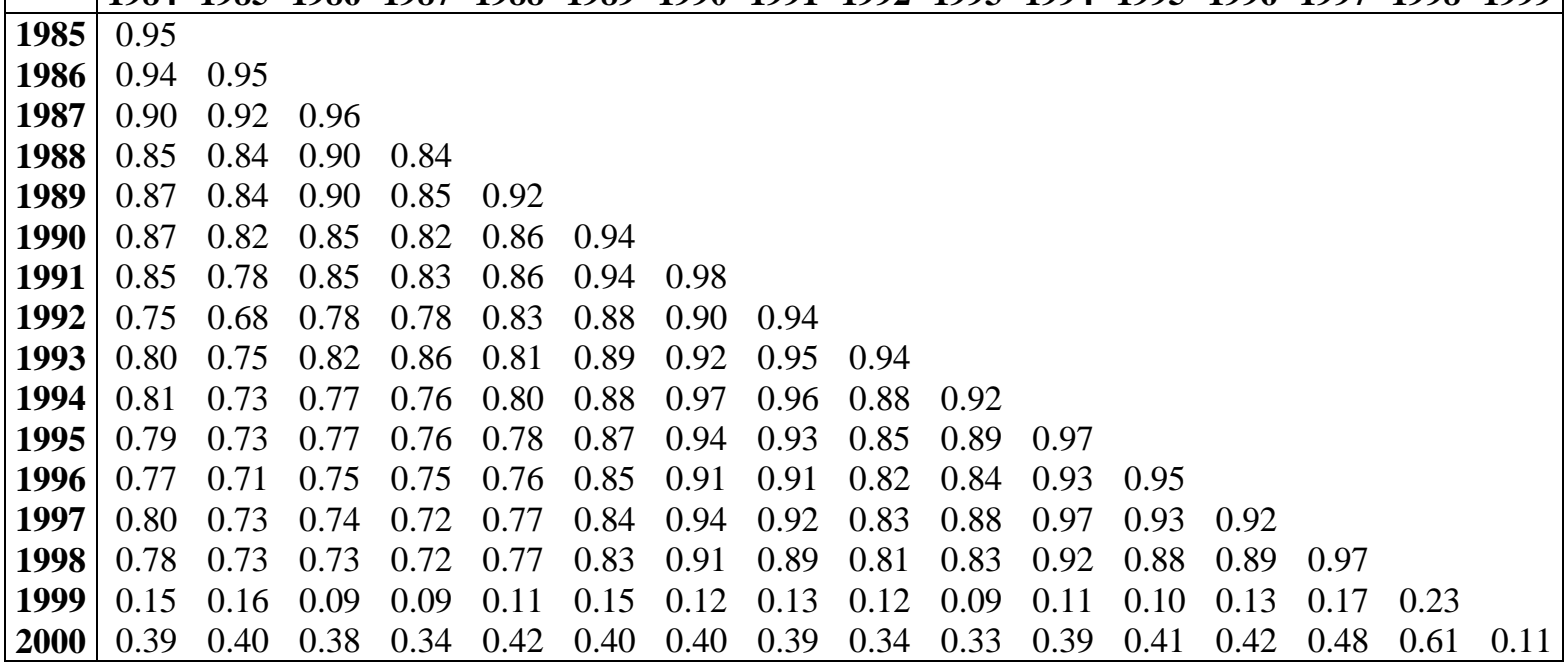


Table 9: Basic results for fixed-effects model (11)

\begin{tabular}{lrr}
\hline \hline & Coefficient & t-statistic \\
\hline Years of schooling & 0.0722 & 9.4 \\
Age & 0.0443 & 65.24 \\
Age-squared & -0.0004 & -54.96 \\
\hline$\sigma_{u}^{2}$ & 0.323 & \\
$\sigma_{e}^{2}$ & 0.161 & \\
$\sigma_{u}^{2} /\left(\sigma_{u}^{2}+\sigma_{e}^{2}\right)$ & 0.67 & \\
\hline $\mathbf{R}^{2}$ & 0.121 & \\
\hline Number of individuals & 39,399 & \\
Number of observations & 458,204 & \\
\hline \hline
\end{tabular}

Table 10: Summary statistics for $R$ and $K$.

\begin{tabular}{|c|c|c|c|c|}
\hline & \multicolumn{2}{|c|}{ Permanent shocks } & \multicolumn{2}{|c|}{ Transitory shocks } \\
\hline & $\mathbf{R}$ & $\mathbf{K}$ & $\mathbf{R}$ & $\mathbf{K}$ \\
\hline Mean & 0.1483 & 0.5195 & 0.3027 & 0.0372 \\
\hline Stand. Dev. & 0.3080 & 3.1852 & 0.1086 & 0.1082 \\
\hline \multicolumn{5}{|l|}{ Percentiles } \\
\hline $10^{\text {th }}$ & 0.0313 & 0.0044 & 0.1990 & -0.0086 \\
\hline $25^{\text {th }}$ & 0.0500 & 0.0137 & 0.2336 & 0.0020 \\
\hline $50^{\text {th }}$ & 0.0737 & 0.0383 & 0.2810 & 0.0134 \\
\hline $75^{\text {th }}$ & 0.1390 & 0.1215 & 0.3413 & 0.0348 \\
\hline 90th & 0.2634 & 0.4679 & 0.4444 & 0.0767 \\
\hline
\end{tabular}

Table 11: Omitted variable bias test

\begin{tabular}{l|rr}
\hline \hline & Model 1 & Model 2 \\
\hline Risk (PS) & -0.275 & \\
& $(-1.46)$ & \\
Skewness (PS) & 0.017 & \\
& $(0.97)$ & \\
Risk (TS) & & 1.557 \\
& & $(0.74)$ \\
Skewness (TS) & & -3.549 \\
& & $(-1.49)$ \\
\hline \hline
\end{tabular}

TS: Transitory shocks; PS=Permanent shocks 
Table 12: Estimation of equation (9) using transitory and permanent shocks

\begin{tabular}{l|rrr|rrr}
\hline \hline & \multicolumn{3}{|c|}{$\mathbf{1 9 8 4}$} & \multicolumn{3}{c}{ 2000 } \\
\hline Risk (PS) & Model 1 & Model 2 & Model 3 & Model 1 & Model 2 & Model 3 \\
& 0.3426 & & 0.2791 & 0.4743 & & 0.2838 \\
& $(16.85)$ & & $(10.93)$ & $(20.10)$ & & $(9.41)$ \\
& 0.0485 & & 0.0395 & 0.0672 & & 0.0403 \\
Skewness (PS) & -0.0256 & & -0.0132 & -0.0362 & & -0.0218 \\
& $(-10.01)$ & & $(-3.50)$ & $(-11.96)$ & & $(-4.83)$ \\
& -0.0041 & & -0.0021 & -0.0058 & & -0.0035 \\
Risk (TS) & & 3.8468 & 1.4827 & & 6.3753 & 4.0249 \\
& & $(13.59)$ & $(4.18)$ & & $(20.21)$ & $(10.00)$ \\
& & 0.1142 & 0.0445 & & 0.1912 & 0.1207 \\
Skewness (TS) & & & & -1.5514 & -1.6788 \\
& & -0.8047 & -2.4304 & & $(-3.64)$ & $(-2.26)$ \\
& & $(-2.33)$ & $(-3.86)$ & & -0.0053 & -0.0057 \\
\hline \hline
\end{tabular}

TS: Transitory shocks; PS: Permanent shocks.

t-values in parentheses

Elasticity in italic

Table 13: Correlations between risk and skewness for TS and PS

\begin{tabular}{|l|ccc|}
\hline & Risk (PS) & Skewness (PS) & Risk (TS) \\
\hline Skewness (PS) & 0.9192 & & \\
Risk (TS) & 0.5940 & 0.4790 & \\
Skewness (TS) & 0.7521 & 0.7473 & 0.6490 \\
\hline
\end{tabular}

TS: Transitory shocks; PS: Permanent shocks. 
Table 14: Estimation of equation (9) using transitory earnings mobility measures

\begin{tabular}{|c|c|c|c|c|}
\hline & \multicolumn{2}{|c|}{1984} & \multicolumn{2}{|c|}{2000} \\
\hline & Coefficient & Elasticity & Coefficient & Elasticity \\
\hline Rank correlation (1- $\rho)$ & $\begin{array}{r}0.0526 \\
(4.94)\end{array}$ & 0.074 & $\begin{array}{r}0.0496 \\
(4.09)\end{array}$ & 0.070 \\
\hline \multicolumn{5}{|l|}{ Mobility quartile ratio } \\
\hline Immobility: $Q_{k=l}(t, t+5)$ & $\begin{array}{r}-0.0030 \\
(-2.11)\end{array}$ & -0.083 & $\begin{array}{r}-0,0102 \\
(-6.33)\end{array}$ & -0.282 \\
\hline Downward mobility: $1-Q_{k>l}(t, t+5)$ & $\begin{array}{r}-0.0120 \\
(-7.75)\end{array}$ & -0.420 & $\begin{array}{r}-0.0062 \\
(-3.49)\end{array}$ & -0.217 \\
\hline Upward mobility: $1-Q_{k<l}(t, t+5)$ & $\begin{array}{r}0.0218 \\
(11.95) \\
\end{array}$ & 0.813 & $\begin{array}{r}0.0275 \\
(12.77) \\
\end{array}$ & 1.026 \\
\hline \multicolumn{5}{|l|}{ Mobility decile ratio } \\
\hline Immobility: $Q_{k=l}(t, t+5)$ & $\begin{array}{r}-0.0058 \\
(-2.85)\end{array}$ & -0.069 & $\begin{array}{r}-0.0130 \\
(-5.43)\end{array}$ & -0.156 \\
\hline Downward mobility: $1-Q_{k>l}(t, t+5)$ & $\begin{array}{r}-0.0108 \\
(-7.76)\end{array}$ & -0.459 & $\begin{array}{r}-0.0054 \\
(-3.48)\end{array}$ & -0.229 \\
\hline Upward mobility: $1-Q_{k<l}(t, t+5)$ & $\begin{array}{r}0.0170 \\
(10.91) \\
\end{array}$ & 0.773 & $\begin{array}{r}0.0144 \\
(8.02) \\
\end{array}$ & 0.655 \\
\hline$-\chi^{2}$ & $\begin{array}{r}-0.1094 \\
(-4.62)\end{array}$ & 0.087 & $\begin{array}{r}-0.1648 \\
(-6.17)\end{array}$ & 0.131 \\
\hline Per-capita decile mobility & $\begin{array}{r}0.0114 \\
(3.19) \\
\end{array}$ & 0.006 & $\begin{array}{r}0.0010 \\
(2.29)\end{array}$ & 0.005 \\
\hline Sample size & 31 , & & 29 , & \\
\hline
\end{tabular}

